\title{
MATHEMATICAL MODELLING AND IMMEDIATE AND LATENT QUALITY OF NATURAL IMMATURE COFFEE UNDER DIFFERENT DRYING CONDITIONS
}

\author{
Ednilton T. de Andrade ${ }^{1}$, Isabella A. Lemos ${ }^{1}$, Camila de A. Dias ${ }^{1}$, Paula de A. Rios ${ }^{1 *}$, \\ Flávio M. Borém ${ }^{1}$
}

\author{
${ }^{1 *}$ Corresponding author. Universidade Federal de Lavras/ Lavras - MG, Brasil. \\ E-mail: paulariosagricola@gmail.com | ORCID ID: https://orcid.org/0000-0002-2836-918X
}

\section{KEYWORDS \\ Drying kinetics, Coffea arabica L., post harvest.}

\begin{abstract}
This work aimed to study the immediate and latent effects of different relative humidities on the quality of dried coffee fruits, describe the drying kinetics of natural immature coffee (Coffea arabica L.), and evaluate the mathematical model that best fits the experimental drying data. The drying was carried out in a fixed layer dryer coupled to a composite air conditioning system in which the drying air was controlled with an air flow of $20 \mathrm{~m}^{3} \cdot \mathrm{min}^{1} \cdot \mathrm{m}^{-2}$, at a temperature of $40{ }^{\circ} \mathrm{C}$, and at relative humidities of $10 \%, 17.5 \%$ and $32.5 \%$. Manually harvested coffee fruits were used and dried to a mean water content of 0.120 dry basis (d.b). After drying, the kinetic curve and the physical and physiological properties were determined. The coffee was stored in permeable packs for 6 months. The electrical conductivity, potassium leaching, and colour analysis were performed every 2 months. For the modelling adjustment, the models were tested, and the Midilli model had the best fit with the drying kinetics of the immature coffee. No immediate damage was observed in the physical and physiological quality of the coffees, and latent damage was perceived after 120 days of storage for the natural immature coffees.
\end{abstract}

\section{INTRODUCTION}

Strip harvesting is the predominant coffee harvesting method in Brazil, and it yields a very heterogeneous product consisting of ripe (cherry), unripe (green) and overripe (raisins and dried-on-trees) berries; foreign materials; and impurities (Borém, 2014). Additionally, coffee has a high water content at the time of harvest compared to other grains (Botelho et al., 2016). Therefore, drying is a critically important post-harvest step and should be started soon after harvesting to quickly reduce the high water content of the berries and prevent fermentation, which may impair coffee quality (Resende et al., 2009).

After harvest, the coffee is processed. In the dry processing, the berries are dried whole, resulting in natural coffee, whereas wet processing results in parchment coffees, with the peel, pulp, and mucilaginous material removed. During the wet processing stage, ripe berries are separated from unripe berries by peeling, with the ripe berries being peeled, and the whole unripe berries being directed down a different path, thus generating two different coffee portions (Borém, 2008). Additionally, according to Borém (2014), the coffee processing stage also aims to separate the berries into more homogeneous lots. The berries may be separated by maturation stage, water content, size and density, among other factors, which facilitate subsequent operations, especially drying and thereby avoiding possible compromises in the quality of the beverage. For coffee drying, the currently available technology allows increasing the drying rate by increasing the temperature, the airflow or by decreasing the relative humidity. The development of technologies or methodologies that provide rapid dehydration without the use of high drying temperatures is a highly promising alternative, especially for the reduction of processing time.

The preservation of bean quality during drying is based on the premise that reducing the amount of available water leads to a reduction in water activity and, consequently, in the speed of chemical and biochemical reactions, as well as the development of microorganisms, allowing safe storage for longer periods (Araujo et al., 2014). Dry processed coffees are more sensitive to drying at high temperatures than wet processed coffees, resulting in lower physiological performance (Alves et al., 2017).

An alternative for increasing the drying rate without causing thermal damage to the beans is to reduce the relative humidity of the drying air by other means, such as by circulating the air through a desiccant that adsorbs

\footnotetext{
${ }^{1}$ Universidade Federal de Lavras/ Lavras - MG, Brasil.

Received in: 9-11-2018

Accepted in: 2-14-2019
} 
and removes moisture from the drying air or by reducing the air dew point temperature (Ondier et al., 2010; Isquierdo et al., 2013).

To simulate the coffee drying process, whose principle is based on the drying of successive thin layers of the product, a mathematical model that satisfactorily represents the water loss is used (Giner \& Mascheroni, 2002). Thin-layer drying of agricultural products allows the drying rates of the product to be determined by collecting data on the mass losses that occur in a sample during the water removal (Monte et al., 2008). Thus, thin-layer drying curves vary according to the species, variety, environmental conditions and postharvest preparation method, among other factors.

Most coffee goes through a period of storage until it is marketed, and therefore, the storage conditions can change its physical, chemical and sensory characteristics (Oliveira et al., 2015). Damages caused by drying may arise in a latent manner, causing changes in coffee quality.

Different analyses are used as indicators of coffee quality by providing information on the physical and physiological state of the product and promoting an understanding of the phenomena and/or changes that occur in beans subjected to different postharvest processes. Previous studies have correlated the maintenance of physiological quality during this process with the sensory quality of the beverage (Borém et al. 2014; Oliveira et al., 2015; Alves et al., 2017).

The colour of immature coffee beans may be related to the quality of the beverage and is an important factor for the valorisation of the product. Changes in colour are strong indicators that oxidative processes and enzymatic biochemical transformations that alter the composition of the precursors responsible for the flavour and aroma of the beverage have occurred, thereby resulting in decreased quality (Borém et al., 2013; Rendón et al., 2014; Abreu et al., 2015).

The paucity of studies on the drying of immature coffee, which shows heterogeneity of the maturation stages when harvested, increases the importance of theoretical research on the drying process of agricultural products; therefore, the objective of this study was to obtaining the drying curves of unripe coffee berries (Coffea arabica L.) using mathematical models. A secondary objective was to determine the immediate and latent effects of different relative humidities during drying on the quality of the coffee berries.

\section{MATERIAL AND METHODS}

The present study was conducted at the Agricultural Products Processing Laboratory, Department of Engineering, Federal University of Lavras (Universidade Federal de Lavras - UFLA). The experiment used unripe coffee beans (Coffea arabica L. cv. Catuaí Vermelho IAC 99) selectively harvested in a commercial plantation of the Três Porteiras property, located in the municipality of Ingaí, Minas Gerais, Brazil. All harvesting and processing procedures were performed according to Borém (2014).
A fixed-bed dryer coupled to an air conditioning system was used for drying, and a drying air temperature of $40{ }^{\circ} \mathrm{C}$ was adopted. The air characteristics were controlled by a Laboratory Air Conditioning System (LACS) model proposed by Fortes et al. (2006). This equipment allows the flow rate $\left(20 \mathrm{~m}^{3} \cdot \mathrm{min}^{-1} \cdot \mathrm{m}^{-2}\right)$, temperature $(\mathrm{T})$ and relative humidity $(\mathrm{RH})$ of the air to be accurately controlled during drying. Three relative humidity values were tested: $10 \pm 2 \%$, $17.5 \pm 2 \%$ and $32.5 \pm 2 \%$. The air flow was regulated by a frequency inverter (Weg, model CFW-10).

The dew point temperature was measured inside the LACS chamber, and the drying air temperature was measured in the plenum chamber, under the perforated bottom trays, by thermocouples connected to universal controllers (Novus, model N1100). The relative humidity of the drying air was measured by a portable digital thermohygrometer (Instrutemp, model ITLOG 80) with a sensor inserted inside the plenum chamber. The temperature of the drying air around the coffee berries was measured with mercury thermometers placed at the centre of the sample.

Drying was monitored by the gravimetric method (mass loss) until the desired water content was reached. The trays containing the product were periodically removed from the chamber at half-hour intervals in the first 5 hours and then hourly until the end of the process. An analytical balance (Shimadzu, model UX420H) with a resolution of $0.01 \mathrm{~g}$ was used for weighing, according to the equation below.

$$
\mathrm{Ut}=\frac{\mathrm{Wwi}-(\mathrm{Wti}-\mathrm{Wtt})}{\mathrm{Wdm}}
$$

Where:

Ut is the water content ( $\mathrm{kg}$ water.kg dry matter-1) (dry basis, $\mathrm{db}$ ) at time t;

$\mathrm{WW}_{\mathrm{i}}$ is the initial water weight $(\mathrm{kg})$;

$\mathrm{Wt}_{\mathrm{i}}$ is the initial total weight $(\mathrm{kg})$;

$\mathrm{Wt}_{\mathrm{t}}$ is the total weight at time $\mathrm{t}(\mathrm{kg})$, and

$\mathrm{W}_{\mathrm{dm}}$ is the dry matter weight $(\mathrm{kg})$.

In the analysis of the drying data, the moisture ratio (MR) is essential to describe different thin-layer drying models. The MR during drying as a function of the evaluated variables was determined by [eq. (2)]. For all tested conditions, the MR values as a function of drying time were fitted to models used to describe the drying kinetics of the coffee (Table 1).

$$
\mathrm{MR}=\frac{\mathrm{U}-\mathrm{Ue}}{\mathrm{Ui}-\mathrm{Ue}}
$$

Where:

MR is the moisture ratio (dimensionless);

$\mathrm{U}$ is the water content of the product ( $\mathrm{db}$ ) at time $\mathrm{t}$;

$\mathrm{U}_{\mathrm{e}}$ is the equilibrium water content of the product $(\mathrm{db})$, and

$\mathrm{U}_{\mathrm{i}}$ is the initial water content of the product $(\mathrm{db})$. 
TABLE 1. Mathematical models used to predict drying kinetics.

\begin{tabular}{ll}
\hline Model designation & Model \\
\hline Two-term & $\mathrm{MR}=\mathrm{a} \cdot \exp \left(-\mathrm{k}_{0} \cdot \mathrm{t}\right)+\mathrm{b} \cdot \exp \left(-\mathrm{k}_{1} \cdot \mathrm{t}\right)$ \\
Two-term exponential & $\mathrm{MR}=\mathrm{a} \cdot \exp (-\mathrm{k} \cdot \mathrm{t})+(1-\mathrm{a}) \exp (-\mathrm{k} \cdot \mathrm{a} \cdot \mathrm{t})$ \\
Modified Henderson \& Pabis & $\mathrm{MR}=\mathrm{a} \cdot \exp (-\mathrm{k} \cdot \mathrm{t})+\mathrm{b} \cdot \exp \left(-\mathrm{k}_{0} \cdot \mathrm{t}\right)+\mathrm{c} \cdot \exp \left(-\mathrm{k}_{1} \cdot \mathrm{t}\right)$ \\
Henderson \& Pabis & $\mathrm{MR}=\mathrm{a} \cdot \exp (-\mathrm{k} \cdot \mathrm{t})$ \\
Midilli & $\mathrm{MR}=\mathrm{a} \cdot \exp \left(-\mathrm{k} \cdot \mathrm{t}^{\mathrm{n}}\right)+\mathrm{b} \cdot \mathrm{t}$ \\
Newton & $\mathrm{MR}=\exp (-\mathrm{k} \cdot \mathrm{T})$ \\
Page & $\mathrm{MR}=\exp \left(-\mathrm{k} \cdot \mathrm{T} \mathrm{T}^{\mathrm{n}}\right)$ \\
Thompson & $\mathrm{MR}=\exp \left\{\left[-\mathrm{a}-\left(-\mathrm{a}^{2}+\mathrm{t} \cdot \mathrm{b} \cdot \mathrm{t}\right)^{0.5}\right] \cdot(2 \cdot \mathrm{b})^{-1}\right\}$ \\
Verma & $\mathrm{MR}=-\mathrm{a} \cdot \exp (-\mathrm{k} \cdot \mathrm{t})+(1-\mathrm{a}) \exp \left(-\mathrm{k}_{1} \cdot \mathrm{t}\right)$ \\
Wang and Sing & $\mathrm{MR}=1+\mathrm{a} \cdot \mathrm{t}+\mathrm{b} \mathrm{t}^{2}$ \\
Valcam & $\mathrm{MR}=\mathrm{a}+\mathrm{b} \cdot \mathrm{t}+\mathrm{c} \cdot \mathrm{t}^{\mathrm{t}, 5}+\mathrm{d} \cdot \mathrm{t}^{2}$
\end{tabular}

MR: moisture ratio; t: drying time (h); k, $\mathrm{k}_{0}$ and $\mathrm{k}_{1}$ : drying constants; $\mathrm{a}, \mathrm{b}, \mathrm{c}, \mathrm{d}, \mathrm{n}$ : model coefficients.

To fit the mathematical models, nonlinear regression analyses were performed using the Gauss-Newton method in the software STATISTICA 5.0 ${ }^{\circledR}$ (Statsoft, Tulsa, USA). The best model was selected based on the following statistical parameters: standard deviation of the estimate (SE), mean relative error (P), and coefficient of determination $\left(\mathrm{R}^{2}\right)$. The standard deviation of the estimate and the mean relative error were calculated using eqs (14) and (15), respectively.

$$
\begin{aligned}
& S E=\sqrt{\frac{\sum(\mathrm{Y}-\hat{\mathrm{Y}})^{2}}{\mathrm{DF}}} \\
& \mathrm{P}=\left[\left(\frac{100}{\mathrm{n}}\right) \sum\left(\frac{|\mathrm{Y}-\hat{\mathrm{Y}}-\hat{\mathrm{Y}}|}{\mathrm{Y}}\right)\right]
\end{aligned}
$$

Where:

$\mathrm{SE}$ is the standard deviation of the estimate (decimal);

$\mathrm{Y}$ is the experimentally observed value;

$\hat{\mathrm{Y}}$ is the value calculated by the model;

DF is the degrees of freedom of the model (number of model parameters -1 );

$\mathrm{P}$ is the mean relative error $(\%)$, and

$\mathrm{n}$ is the number of observed datapoints.

To characterize the coffee quality, the physical and physiological properties of the coffee were determined after drying and then every 2 months during the 6 months of storage.

Colour quantification was performed using a colourimeter (Minolta CR-410) previously calibrated on a white surface according to pre-established standards (Bible $\&$ Singha, 1993). Measurements were performed directly on the beans, which were placed on a glass Petri dish so that the beans covered the entire surface on which the readings were taken, maintaining their integrity.

The electrical conductivity of the raw beans was determined according to the method proposed by Krzyzanowski et al., (1991). For this purpose, two replicates of 50 grains of each sample were weighed at $0.001 \mathrm{~g}$ precision and immersed in $75 \mathrm{~mL}$ of distilled water inside 200-mL plastic cups. Then, these containers were placed for $5 \mathrm{~h}$ in a forced-air biochemical oxygen demand chamber (Quimis, model Q-315D) regulated to $25{ }^{\circ} \mathrm{C}$, after which time the electrical conductivity of the imbibition water was read using a benchtop conductivity meter (BEL, model W12D). After the readings were obtained, the electrical conductivity was calculated using [eq. (16)], and the results were expressed in $\mu \mathrm{S} . \mathrm{cm}^{-1} \cdot \mathrm{g}^{-1}$ of grains.

$$
\mathrm{CE}=\frac{\mathrm{CE}^{\prime}}{\text { Weight }(\mathrm{g})}
$$

Where:

$\mathrm{CE}^{\prime}$ is the electrical conductivity reading $\left(\mu \mathrm{S} . \mathrm{cm}^{-1}\right)$.

The leaching of potassium ions was measured in the raw beans after the electrical conductivity reading, and the same solutions were subjected to determination of the amount of leached potassium. The reading was performed in a flame photometer (Digimed, Model NK-2002). With the data obtained, the amount of leached potassium was calculated according to [eq. (17)], and the results were expressed in parts per million (ppm).

$$
\mathrm{LK}=\frac{\left(\mathrm{LK}^{\prime} \times \text { Dilution } \times 1.56\right)}{\text { Weight }(\mathrm{g})}
$$

Where:

$\mathrm{LK}^{\prime}$ is the potassium leaching reading (ppm). 
The percentage of black-green defective beans in the raw bean samples was determined. From a sample of natural unripe coffee processed manually, 100 beans were counted and separated into immature and black-green defective beans, with percentages being directly obtained.

The experiment was set up in a $3 \times 1 \times 4$ factorial arrangement (three drying relative humidities), one coffee type (natural immature) and four storage times in a completely randomized design, with four replications per drying treatment, corresponding to each of the dryer trays. The airflow rate adopted was $20 \mathrm{~m}^{3} \cdot \mathrm{min}^{1} \cdot \mathrm{m}^{-2}$, with an air temperature $40{ }^{\circ} \mathrm{C}$ and relative humidities of $10 \pm 2 \%, 17.5$ $\pm 2 \%$ and $32.5 \pm 2 \%$. The coffee was stored for 6 months, with physiological assessments performed every 2 months.

\section{RESULTS AND DISCUSSION}

Table 2 shows the values of the statistical parameters coefficient of determination $\left(\mathrm{R}^{2}\right)$, mean relative error $(\mathrm{P})$ and standard deviation of the estimate (SE) used to compare the eleven analysed drying models under the three tested immature coffee drying conditions.

TABLE 2. Coefficient of determination $\left(\mathrm{R}^{2}, \%\right)$, mean relative error $(\mathrm{P}, \%)$ and standard deviation of the estimate $(\mathrm{SE}$, decimal) values obtained for the analysed models describing the drying kinetics of natural immature coffee under different relative humidity.

\begin{tabular}{lccccccccc}
\hline \multicolumn{1}{c}{ Model } & $\mathrm{R}^{2}$ & $\mathrm{P}$ & $\mathrm{SE}$ & $\mathrm{R}^{2}$ & $\mathrm{P}$ & $\mathrm{SE}$ & $\mathrm{R}^{2}$ & $\mathrm{P}$ & $\mathrm{SE}$ \\
\hline & & $\mathrm{RH}=10 \%$ & & & $\mathrm{RH}=17.5 \%$ & & \multicolumn{2}{c}{$\mathrm{RH}=32.5 \%$} \\
\hline Two-term & 99.84 & 1.015 & 0.146 & 99.38 & 2.439 & 0.355 & 99.69 & 1.426 & 0.275 \\
Modified Henderson \& Pabis & 99.84 & 1.015 & 0.113 & 99.38 & 2.441 & 0.275 & 99.69 & 1.443 & 0.215 \\
Henderson \& Pabis & 99.84 & 1.015 & 0.253 & 99.38 & 2.438 & 0.614 & 99.69 & 1.426 & 0.476 \\
Midilli & 99.96 & 0.014 & 0.002 & 99.97 & 0.000 & 0.000 & 99.99 & 0.004 & 0.001 \\
Newton & 99.78 & 0.508 & 0.127 & 99.29 & 1.708 & 0.430 & 99.61 & 0.863 & 0.288 \\
Page & 99.94 & 0.510 & 0.127 & 99.79 & 1.798 & 0.453 & 99.92 & 0.848 & 0.283 \\
Thompson & 99.95 & 0.023 & 0.006 & 99.95 & 0.358 & 0.090 & 99.98 & 0.050 & 0.017 \\
Verma & 99.92 & 0.340 & 0.060 & 99.82 & 0.341 & 0.061 & 99.67 & 1.369 & 0.323 \\
Wang and Sing & 98.99 & 2.331 & 0.581 & 99.34 & 2.255 & 0.568 & 99.16 & 1.946 & 0.649 \\
Valcam & 99.91 & 0.000 & 0.000 & 99.93 & 0.000 & 0.000 & 99.94 & 0.000 & 0.000 \\
Two-term exponential & 99.78 & 0.602 & 0.150 & 99.29 & 1.754 & 0.442 & 99.24 & 1.201 & 0.401 \\
Diffusion approximation & 99.94 & 0.398 & 0.070 & 99.83 & 1.559 & 0.278 & 99.91 & 0.830 & 0.196 \\
\hline
\end{tabular}

All fitted models had satisfactory coefficients of determination $\left(\mathrm{R}^{2}>90 \%\right)$ and mean relative error below $10 \%$, indicating that these models are suitable for representing the studied phenomenon (Mohapatra \& Rao, 2005). According to Kashaninejad et al. (2007), the mean relative error values indicate deviation of the observed values relative to the curve estimated by the model. Thus, together with this statistical parameter, the goodness-of-fit of the model was adapted as an additional criterion to all studied relative humidities during drying.

Thus, based on all statistical parameters used, the model chosen to represent the natural immature coffee drying phenomenon for all relative humidities studied was the Midilli model. The $\mathrm{R}^{2}$ was greater than $99.9 \%$, and the SE values were less than 0.05 for all studied relative humidities.
This model was also used by Coradi et al., (2017) to describe the drying of de-pulped coffee. Corrêa et al. (2010) also recommended the Midilli mathematical model to describe the drying kinetics of coffee berries because of the satisfactory fit obtained. The Midilli model also showed satisfactory fit to the drying data of several other agricultural products, such as strawberry (Sousa et al., 2014), cowpea (Camicia et al., 2015) and garlic (Cagnin et al. 2017). In addition to being an internationally recognized model, the Midilli model is mathematically more practical, presenting a smaller number of parameters, making its application and use simpler in drying simulations.

Table 3 shows the coefficients of the mathematical model chosen based on the statistical selection criteria in the modelling of drying curves for natural immature coffee at the relative humidities of $10 \%, 17.5 \%$ and $32.5 \%$.

TABLE 3. Coefficients of the mathematical model chosen based on the statistical selection criteria fitted to the drying curve of natural coffee for the three relative humidities studied.

\begin{tabular}{ccccccc}
\hline \multirow{2}{*}{ Model } & RH $(\%)$ & \multicolumn{5}{c}{ Coefficients } \\
\cline { 3 - 6 } & & $\mathrm{a}$ & $\mathrm{k}$ & $\mathrm{n}$ & $\mathrm{b}$ \\
\hline \multirow{2}{*}{ Midilli } & 10 & 0.997120 & 0.031255 & 1.045390 & -0.000232 \\
& 17.5 & 0.977648 & 0.023759 & 1.109212 & -0.000467 \\
& 32.5 & 0.989149 & 0.023013 & 1.079989 & -0.000262 \\
\hline
\end{tabular}


As shown in Table 3, the drying constant ' $\mathrm{k}$ ' is higher for the relative humidity of $10 \%$ when compared to the relative humidity of $32.5 \%$. This finding, which is easily observed in Figure 1, is expected because lower relative humidity leads to a higher drying rate, with the equilibrium water content being achieved in less exposure time for the product to the drying air.

Figure 1 shows the behaviour of the moisture ratio observed and estimated by the Midilli model for immature coffee at the relative humidities of $10 \%, 17.5 \%$ and $32.5 \%$ during drying.

As expected, when berries were dried in high relative humidity of $32.5 \%, 75$ hours of drying were required, which was longer than required under the drying air condition with lower relative humidity of $10 \%$, which required 62.5 hours. The values estimated by the Midilli model showed satisfactory representation, with sufficient fidelity in the description of the drying behaviour.

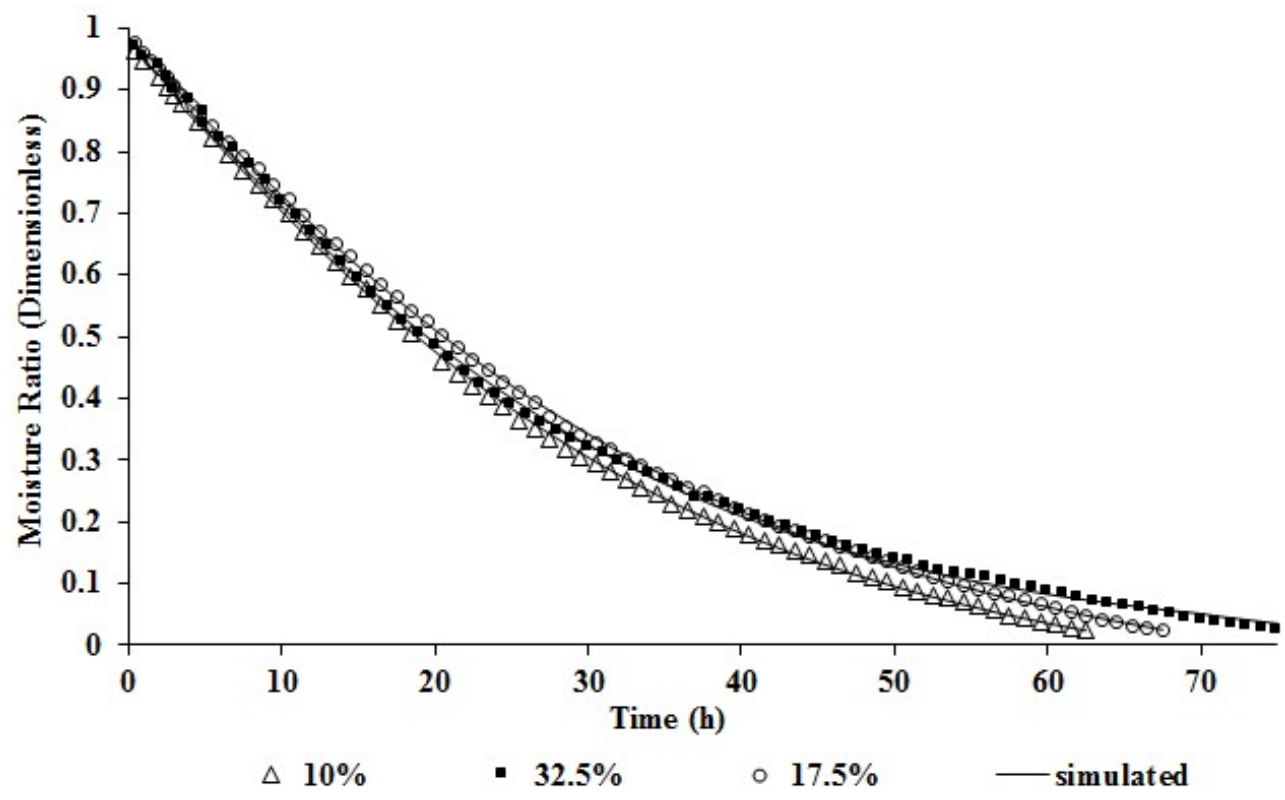

FIGURE 1. Moisture ratio values of observed and estimated by the Midilli model for drying natural immature coffee at the relative humidity of $10 \%, 17.5 \%$ and $32.5 \%$ as a function of time.

Figures 2, 3 and 4 show the behaviour of the drying kinetics at $40{ }^{\circ} \mathrm{C}$ and relative humidity of $10 \%, 17.5 \%$ and $32.5 \%$, respectively, as well as the behaviour of the water reduction rate under each condition.

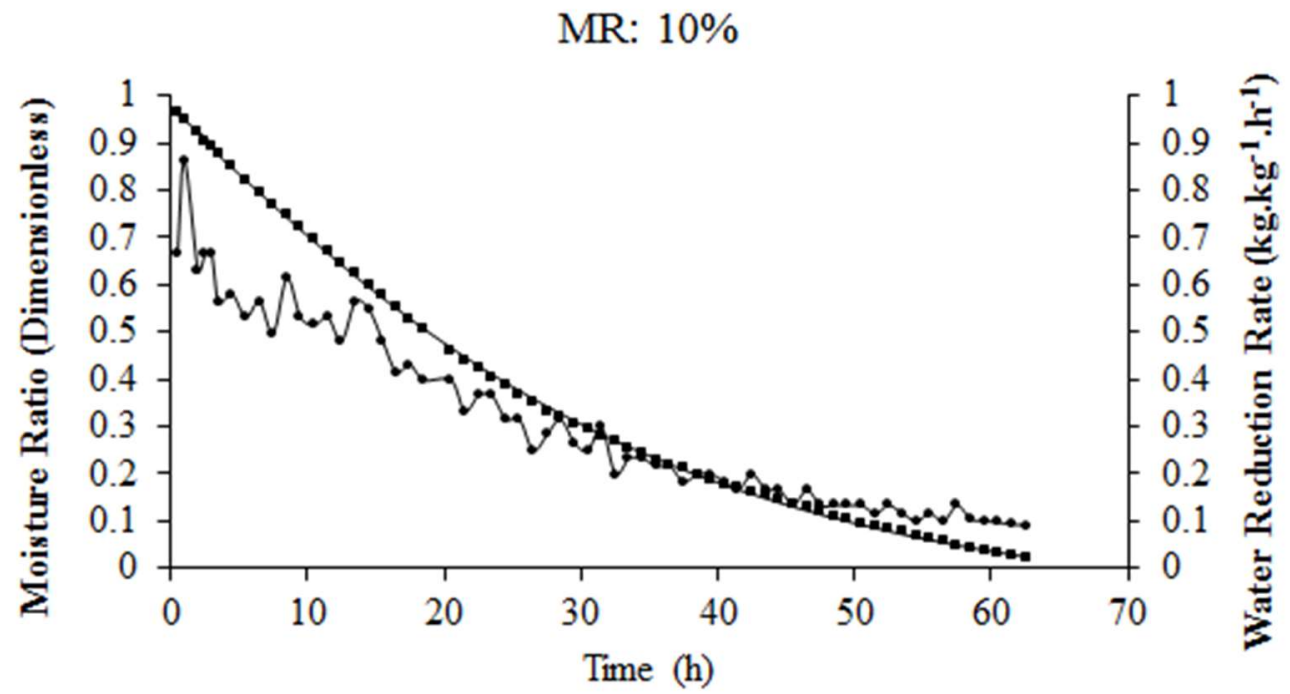

- MR observed - MR simulated $\rightarrow$ Water Reduction Ratio

FIGURE 2. Moisture ratio values observed and estimated by the Midilli model and water reduction rate for natural immature coffee drying at $10 \%$ relative humidity and temperature of $40{ }^{\circ} \mathrm{C}$ as a function of time. 
MR: $17.5 \%$

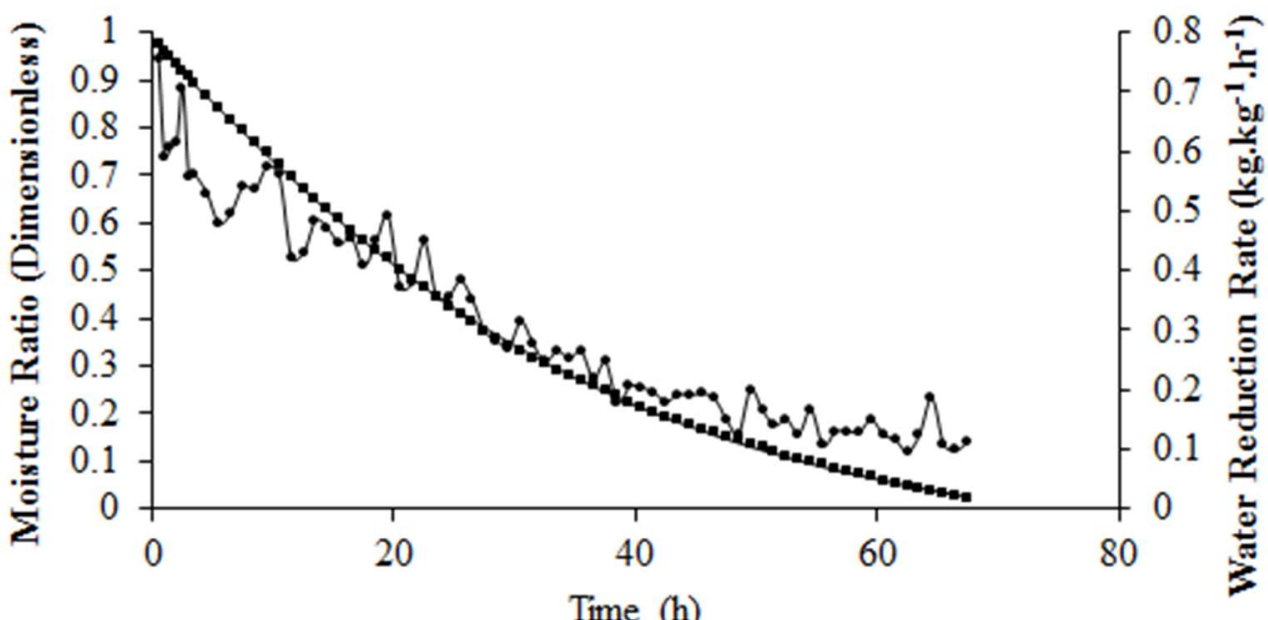

- MR observed $\quad$ MR simulated $\rightarrow$ Water Reduction Rate

FIGURE 3. Moisture ratio values observed and estimated by the Midilli model and water reduction rate for natural immature coffee drying at $17.5 \%$ relative humidity and temperature of $40{ }^{\circ} \mathrm{C}$ as a function of time.

MR: $32.5 \%$

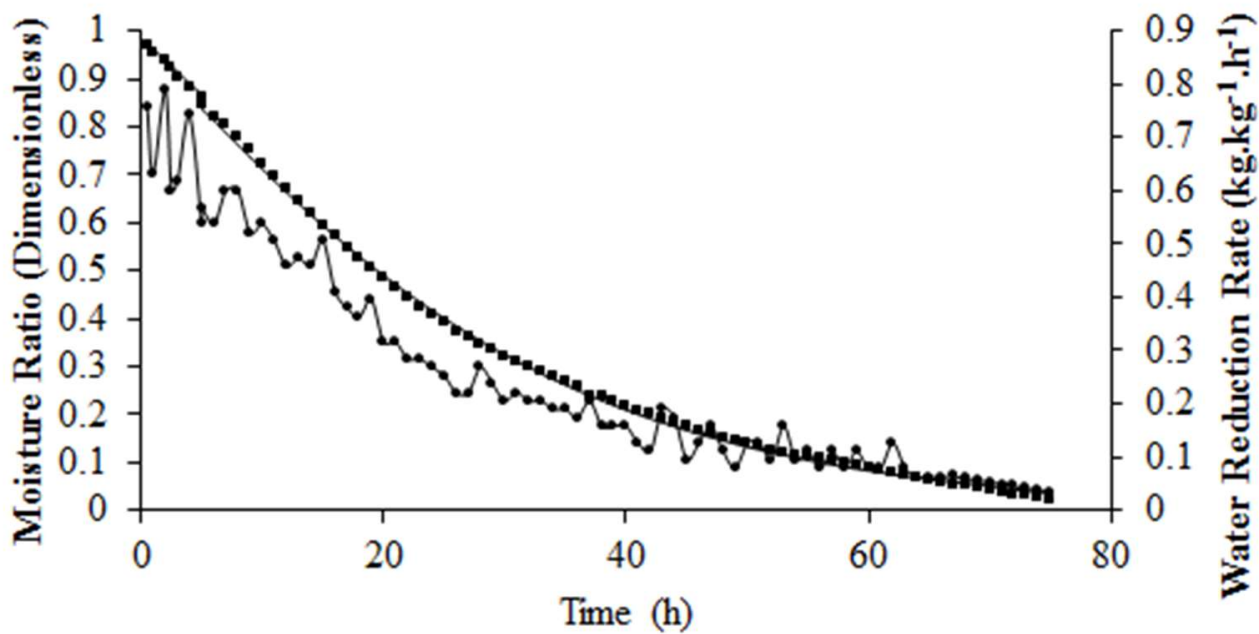

\section{- MR observed -MR simulated $\rightarrow$ Water Reduction Rate}

FIGURE 4. Moisture ratio values observed and estimated by the Midilli model and water reduction rate for natural immature coffee drying at $32.5 \%$ relative humidity and temperature of $40{ }^{\circ} \mathrm{C}$ as a function of time.

Under all drying conditions, the initial water reduction rate was higher, which occurs because the capillary and solvent water are freer in the bean and are more easily removed during drying.
Table 4 shows the mean values of the potassium leaching test of natural immature coffee for the interaction of the factors of relative humidity during drying and the storage time.

TABLE 4. Mean potassium leaching (LK) values of natural immature coffee for the interaction of the relative humidity during drying and the storage time factors.

\begin{tabular}{ccccc}
\hline \multirow{2}{*}{ Coffee type } & Storage time (days) & \multicolumn{3}{c}{ Relative humidity (\%) } \\
\cline { 3 - 5 } & & 40 & 17.5 & 32.5 \\
\hline \multirow{2}{*}{ Natural } & 60 & $799.285 \mathrm{Aa}$ & $406.189 \mathrm{Aa}$ & $422.022 \mathrm{Aa}$ \\
immature & 120 & $938.825 \mathrm{Bc}$ & $722.092 \mathrm{Bb}$ & $581.082 \mathrm{Ab}$ \\
& 180 & $916.769 \mathrm{Ac}$ & $887.364 \mathrm{Ab}$ & $660.606 \mathrm{Ac}$ \\
\end{tabular}

Means followed by the same uppercase letter in the rows and lowercase letters in the columns do not differ significantly at the $5 \%$ probability level by the Scott-Knott test. 
The potassium leaching values varied during storage, and the longer the storage time was, the higher the values obtained. That is, the coffee suffered physiological damage during storage. The potassium leaching values were influenced by the effect of the relative humidity during drying on the storage times, and in general, the highest potassium leaching values were found in natural immature coffee beans dried at a relative humidity of $10 \%$. This finding suggests that the lower the relative humidity used, i.e., the faster drying, the greater the cellular damage to the coffee because this test is indicative of cellular disorganization (Malta et al., 2013). Immature coffee has thinner cell walls due to the low cellulose content, which is accompanied by greater loss of permeability control and solute leakage. As in the present study, Isquierdo et al. (2011) found that the lower the relative humidity is during drying, the greater the damage is to the cell membranes of natural coffee. Notably, the compounds of immature coffees are not yet fully formed and thus can experience more intense damage, leading to membrane disorganization during the drying processes when the drying rate is higher and water evaporates more quickly, causing greater potassium leaching.

The evolution of the colour of immature coffee was another parameter used to characterize quality. The mean values of the $L^{*}$ and $b^{*}$ coordinates of the beans obtained from natural immature coffee according to the relative humidity of the drying air are shown in Table 5, which indicates the influence of this factor on the colour of the product. Values of the $\mathrm{a}^{*}$ coordinate were not included, as they showed no significant trend. In general, an increase in the $\mathrm{L}^{*}$ and $\mathrm{b}^{*}$ coordinate values is observed when the relative humidity during drying is $32.5 \%$, suggesting that in the slower drying processes, the beans have higher luminosity and decreased bluish tone, characteristics desirable for coffee beans.

TABLE 5. Mean $\mathrm{L}^{*}$ and $\mathrm{b}^{*}$ coordinate values for beans from natural immature coffee subjected to different drying conditions and stored for 180 days.

\begin{tabular}{lcccc}
\hline Coffee type & Relative humidity (\%) & Drying time (hours) & L* coordinate & b* coordinate \\
\hline \multirow{2}{*}{ Natural immature } & 10 & 81.3 & $31.063 \mathrm{a}$ & $17.596 \mathrm{a}$ \\
& 17.5 & 83.5 & $31.361 \mathrm{a}$ & $17.491 \mathrm{a}$ \\
& 32.5 & 99.5 & $33.590 \mathrm{~b}$ & $18.553 \mathrm{~b}$ \\
\hline
\end{tabular}

Means followed by different letters differ significantly by the Scott-Knott test at 5\% probability.

The mean $\mathrm{L}^{*}$ coordinate values obtained from natural immature coffee beans, according to storage time, are shown in Table 6, with an increase observed in the values of the coordinates analyzed with the extension of the storage time.

TABLE 6. Mean L* coordinate values for natural immature coffee beans subjected to different drying conditions and stored for 180 days.

\begin{tabular}{ccc}
\hline Coffee type & Storage time (days) & L* coordinate \\
\hline & 0 & $29.244 \mathrm{a}$ \\
Natural immature & 60 & $32.657 \mathrm{~b}$ \\
& 120 & $33.979 \mathrm{c}$ \\
\hline
\end{tabular}

Means followed by different letters differ by the Scott-Knott test at 5\% probability.

Bleaching is a known phenomenon during the storage of processed coffee beans and is explained by the increase in the $\mathrm{L}^{*}$ coordinate values. Increases in the $\mathrm{a}^{*}$ and $b^{*}$ coordinates indicate the loss of the green and bluish colour of the beans, respectively (Afonso Júnior \& Corrêa, 2003).

The colour of the natural immature coffee beans showed an increase in the $\mathrm{L}^{*}$ coordinate value over the storage time and consequently experienced higher bleaching rates. This result for processed natural coffees, in addition to the bleaching factor, may be due to the presence of spermoderm (silver skin) fragments adhering to the beans, which may have influenced the reading of the apparatus (Abreu et al., 2015).

The percentages of black-green defective beans in the natural immature coffee sample, according to the relative humidity during drying, are shown in Table 7.

TABLE 7. Percentage of black-green defective beans obtained after drying of natural immature coffee.

\begin{tabular}{cc}
\hline Relative humidity $(\%)$ & Black-green defective beans $(\%)$ \\
\hline 10 & $33.00 \mathrm{ab}$ \\
17.5 & $37.00 \mathrm{~b}$ \\
32.5 & $31.17 \mathrm{ab}$ \\
\hline
\end{tabular}

Means followed by the same letter do not differ by Tukey's test at $5 \%$ probability. 
Black-green defective beans are characterized by a brilliant black colour because of the adherence of the silver skin. The immature and black-green coffee defects, originating from immature beans, are considered serious defects and negatively affect the quality of the coffee beverage (Brasil, 2003).

The data in Table 7 show that the mean number of defective beans varied among treatments, and for the coffees dried at a relative humidity of $32.5 \%$, a lower percentage of black-green defectives beans was observed compared to the coffees dried at the relative humidity of $17.5 \%$.

The drying temperature is another factor that affects the formation of black-green defective beans during this stage. Enzymes in the beans are thought to react with the substrate (phenolic compounds present near the cell wall), forming brown polymers. The same effect can also be produced by denaturation or oxidation of phenolic compounds, as well as of sugars and proteins (Teixeira et al., 1984).

\section{CONCLUSIONS}

Under the conditions tested in the present study, for the natural immature coffee, the Midilli model had the best fit for representing the drying kinetics, regardless of the relative humidity tested.

Regarding the physiological and physical quality of coffee, natural immature coffee had a better physical and physiological quality when dried at $32.5 \%$ relative humidity.

Drying with low relative humidities does not damage the physical and physiological quality of immature coffee immediately. The latent damage to quality was observed after 120 days of storage.

The mean number of defects varied among the treatments; in the coffees dried at $32.5 \%$ relative humidity, a lower percentage of black-green defective beans was observed compared to those dried at $17.5 \%$ relative humidity.

\section{REFERÊNCIAS}

Abreu GFD, Pereira CC, Malta MR, Clemente ADCS, Coelho LFS, Rosa SDVFD (2015) Alterações na coloração de grãos de café em função das operações pós-colheita. Coffee Science 10(4):429-436.

Afonso Júnior PC, Corrêa PC (2003) Influência do tempo de armazenagem na cor dos grãos de café pré-processados por "via seca" e "via úmida". Ciência e Agrotecnologia, 27(6):1268-1276.

Alves GE, Borém FM, Isquierdo EP, Siqueira VC, Cirillo MÂ, Pinto ACF (2017) Physiological and sensorial quality of arabica coffee subjected to different temperatures and drying airflows. Acta Scientiarum Agronomy 39(2):225233. DOI:

http://dx.doi.org/10.4025/actasciagron.v39i2.31065

Araujo WD, Goneli AL, Souza CD, Gonçalves AA, Vilhasanti HC (2014) Propriedades físicas dos grãos de amendoim durante a secagem. Revista Brasileira de Engenharia Agrícola e Ambiental 18(1): 279-286.

Bible BB, Singha S (1993) Canopy position influences CIELab coordinates of peach color. HortScience 28(10):992-993.
Borém FM (2014) Handbook of coffee post-harvest technology. Norcross, Gin.

Borém FM (2008) Processamento do café. In: Borém FM. Pós-colheita do café. Lavras, UFLA. p 127-158.

Borém, FM, Isquierdo EP, Oliveira PD, Ribeiro FC, Siqueira VC, Taveira JHDS (2014) Effect of intermittent drying and storage on parchment coffee quality. Bioscience Journal 30(2):609-616.

Borém FM, Ribeiro FC, Figueiredo LP, Giomo GS, Fortunato VA, Isquierdo EP (2013) Evaluation of the sensory and color quality of coffee beans stored in hermetic packaging. Journal of Stored Products Research 52:1-6. DOI: https://doi.org/10.1016/j.jspr.2012.08.004

Botelho FM, Corrêa PC, Botelho SCC, Elías GAV, Almeida MDSD, Oliveira GHH (2016) Propriedades físicas de frutos de café robusta durante a secagem: determinação e modelagem. Coffee Science 11(1):65-75.

Brasil (2003) Ministério da Agricultura, Pecuária e Abastecimento. Instrução Normativa $n^{\circ} 8$, de 11 de junho de 2003. Aprova o regulamento técnico da identidade e de qualidade para a classificação do café beneficiado grão cru. Brasília. Available: http:www.agricultura.gov.br. Accessed: Jul 10, 2018.

Cagnin C, Lima MS, Silva RM, Plácido GR, Silva MAP, Freitas BSM, Oliveira DEC (2017) Alho: cinética de secagem e propriedades termodinâmicas. Revista Bioscience Journal 33(4):905-913.

Camicia RG da M, Christ D, Coelho SRM, Camicia RF da M (2015) Modelagem do processo de secagem de sementes de feijão-caupi. Revista Caatinga 28(3):206-214.

Coradi PC, Borém FM, Reinato CH (2017) Mathematical modeling of drying the pulped coffee (Coffea arabica 1.) at different air conditions. Revista Brasileira de Tecnologia Agroindustrial 11(2):2397-2419. DOI: http://dx.doi.org/10.3895/rbta.v11n2.3166

Corrêa PC, Goneli AL, Junior PC, De Oliveira, GH, Valente DS (2010) Moisture sorption isotherms and isosteric heat of sorption of coffee in different processing levels. International Journal of Food Science \& Technology 45(10):2016-2022. DOI: https://doi.org/10.1111/j.1365-2621.2010.02373.x

Fortes M, Ferreira DA, Ferreira WR, de Souza AC (2006) Modelagem de um condicionador de ar de alta precisão para uso em processamento agrícola Modeling of a high precision air conditioner for use in agricultural processing. Engenharia Agrícola 26(2):578-589. DOI: https://doi.org/10.1590/S0100-69162006000200028

Giner SA, Mascheroni RH (2002) Diffusive Drying Kinetics in Wheat, Part 2: applying the Simplified Analytical Solution to Experimental Data. Biosystems Engineering 81(1):85-97. DOI:

http://dx.doi.org/10.1006/bioe.2001.0004 
Isquierdo EP, Borém FM, Cirillo M, de Oliveira PD, Cardoso RA, Fortunato VA (2011) Qualidade do café cereja desmucilado submetido ao parcelamento da secagem. Coffee Science 6(1):83-90. DOI: http://dx.doi.org/10.25186/cs.v6i1.229

Isquierdo EP, Borém FM, de Andrade ET, Corrêa JLG, de Oliveira PD, Alves GE (2013) Drying kinetics and quality of natural coffee. Transactions of the ASABE 56(3):10031010. DOI: http://dx.doi.org/10.13031/trans.56.9794

Kashaninejad M, Mortazavi A, Safekordi A \& Tabil LG (2007) Thin-layer drying characteristics and modeling of pistachio nuts. Journal of Food Engineering 78(1):98-108. DOI: http://dx.doi.org/10.1016/j.jfoodeng.2005.09.007

Krzyzanowski FC, França Neto JB, Henning AA (1991) Relatos dos testes de vigor disponíveis as grandes culturas. Informativo do ABRATES 1(2):15-50.

Malta MR, Rosa SDVF da, Lima PM, de Oliveira Fassio L, Santos JB (2013) Alterações na qualidade do café submetido a diferentes formas de processamento e secagem. Revista Engenharia na AgriculturaReveng 21(5):431-440. DOI: https://doi.org/10.13083/reveng.v21i5.450

Mohapatra D, Rao PS (2005) A thin layer drying model of parboiled wheat. Journal of food engineering 66(4):513518. DOI: https://doi.org/10.1016/j.jfoodeng.2004.04.023

Monte JEC, Martins JH, Lopes DC, Monteiro PMB, Pinto PR (2008) Sistema automático para secagem de produtos agrícolas em camada fina. Acta Scientiarum. Agronomy 30(3):307-312.
Oliveira APLR, Corrêa PC, Reis EL, Oliveira GHH (2015)

Comparative study of the physical and chemical characteristics of coffee and sensorial analysis by principal components. Food Analytical Methods 5(8):1303-1314. DOI: http://dx.doi.org/10.1007/s12161-014-0007-4

Ondier GO, Siebenmorgen TJ, Mauromoustakos A (2010) Low-temperature, low-relative humidity drying of rough rice. Journal of Food Engineering 100(3):545-550. DOI: https://doi.org/10.1016/j.jfoodeng.2010.05.004

Rendón MY, Salva TDJG, Bragagnolo N (2014) Impact of chemical changes on the sensory characteristics of coffee beans during storage. Food chemistry 147:279-286. DOI: https://doi.org/10.1016/j.foodchem.2013.09.123

Resende O, Arcanjo RV, Siqueira VC, Rodrigues S (2009) Modelagem matemática para a secagem de clones de café (Coffea canephora Pierre) em terreiro de concreto. Acta Scientiarum. Agronomy 31(2):189-196. DOI: http://dx.doi.org/10.4025/actasciagron.v31i2.588

Sousa FA, Andrade ET de, Figueira VG, D'Andrea E de M, Corrêa Filho CL (2014) Estudo da cinética de secagem, contração volumétrica e análise da difusão líquida do morango (Fragaria sp.). Engevista 16(1):8-18.

Teixeira AA, Levy FA, Carvalho A (1984) Observações sobre várias características do café colhido verde $\mathrm{e}$ maduro. In: Congresso Brasileiro de Pesquisas Cafeeiras. Rio de Janeiro, Instituto Brasileiro do Café, Anais... 